\title{
Understanding Partnership Challenges in Teacher Recruitment Programs
}

\author{
Mary D. Burbank ${ }^{1}$, Richard Diaz ${ }^{2}$ \\ ${ }^{1}$ The University of Utah Urban Institute for Teacher Education, Salt Lake City, USA \\ ${ }^{2}$ Salt Lake City School, Salt Lake City, USA \\ Email: mary.burbank@utah.edu
}

Received August $30^{\text {th }}, 2012$; revised September 29 $9^{\text {th }}, 2012$; accepted October $11^{\text {th }}, 2012$

\begin{abstract}
This investigation examined perspectives on student eligibility and the curriculum for a teacher education seminar linked to a community-based collaborative. Project data identified: 1) perceptions on the qualifications of pre-service teachers in a recruiting program for first-generation and ethnic minority teachers; and 2) viewpoints on the necessary curriculum for these pre-service teacher participants. Our data indicate varied perspectives by project participants ranging from deficit to asset-based stances regarding prospective teachers from underrepresented communities. Our findings speak to the need for honest conversations within collaborative partnerships designed to diversify the teaching profession.
\end{abstract}

Keywords: Partnerships; Collaboration; Teaching; Diversity

\section{Introduction}

This investigation examined perspectives on student eligibility and the curriculum for a teacher education seminar linked to a community-based collaborative between two institutions of higher education and five school districts in the Salt Lake City Utah in the United States. Project data identified: 1) stakeholder perceptions on the qualifications of prospective teachers in a recruiting program for first-generation and ethnic minority teachers; and 2) viewpoints on the necessary curriculum for teachers in training. Our data indicate varied perspectives by project participants ranging from deficit to asset-based stances regarding prospective teachers from underrepresented communities. Our findings speak to the need for honest conversations within collaborative partnerships designed to diversify the teaching profession.

\section{Theoretical Framework}

The demographic landscape of communities in the United States is changing. Nationally, the number of students from culturally and linguistically diverse communities is increasing. Nearly one third of school-age children are culturally diverse with $16 \%$ of the teaching force from non-majority populations (Gay, Dingus, \& Jackson, 2003; National Center for Education Statistics, 2003; Swartz, 2003). Projections for the next 20 years identify dramatic changes in national demographics where $61 \%$ of population increases will occur among Latinos and Asians with the Latino college-age-population projected to reach 25\% (Excelencia in Education, 2009; Hodgkinson, 2002; Stanford, 1999; Swartz, 2003). For those teaching in K-12 classroom settings, the opportunities to work with increasingly diverse students will become a reality when the number of children of color will become the majority by 2025 (United States Census Bureau, 2008).

The rapid demographic shifts have been particularly significant in Salt Lake City, Utah, with an increase of $117 \%$ among people of color between 1990 and 2000 and an increase from $9 \%$ to $20 \%$ of the total state population between 1990 and 2010 (Perlich, 2011, 2002). The Latino college-age population alone is projected to reach $25 \%$ by 2025 (Excelencia in Education, 2009; Hodgkinson, 2002; Stanford, 1999). These shifts are particularly dramatic within the Salt Lake City's school-aged population where $56 \%$ of students have been identified as non-majority (Salt Lake District Census, 2010).

The purpose of the current work was to examine stakeholder perspectives on a community-based collaborative designed to increase student diversity in a teacher education program. This investigation specifically examined community stakeholders' and students' perspectives on: 1) the characteristics of firstgeneration and ethnically diverse future teachers; and 2) a program curriculum designed to support first-generation and ethnically diverse students as future teachers.

\section{Changing the Profile of the Teaching Profession}

While the makeup of the United States population continues to change, the number of teachers from racially, ethnically, and linguistically diverse groups remains alarmingly low (CochranSmith, 2004; Hodgkinson, 2002; Kane \& Orsini, 2005; Villegas $\&$ Lucas, 2002). Efforts to increase the number of teachers of color have been limited and varied in their intentions with emphases often placed on tuition support and general academic advising (Flores, Clark, Claeys, \& Villarreal, 2007; Guarino, Sanatibañez, \& Daley, 2006). Further, many efforts to diversify the teaching ranks are flawed when solely designed to prepare teachers of color as ambassadors for diverse communities. These intentions are particularly limited in that they may unduly pressure prospective teachers of color and fail to build communities of educators from varied racial, ethnic, and cultural groups (Nieto \& Bode, 2008).

Multilayered recruiting efforts must address changing demographics. Educators whose lives, experiences, and views parallel those of contemporary communities are at no time more 
necessary (Frankenberg, 2009; Gay, 2010; Gay, 2002). Teachers of color bring to classrooms commitments and an understanding of the lives and languages of many contemporary students (Andrews, 2009; Frankenberg, 2009).

In addition to acknowledging the life experiences that many teachers of color may bring to classroom settings, teacher education programs must also examine the fundamentals of curriculum, field-based experiences, and collaboration within neighborhoods and communities (Andrews, 2009; Frankenberg, 2009). These features are particularly central to the teacher education programs affiliated with the Teacher Pipeline Project.

\section{Foundations of Community-Based Research}

The Teacher Pipeline Project began as a community-based collaborative with scholarship support for first-generation students and students of color in their higher education pursuits. The Teacher Pipeline Project reflects the tenets of a community-based research partnership whose fundamental roots stem from embedded campus/community partnerships committed to work designed to collectively meet agreed upon goals (Buys \& Bursnall, 2007; Campbell, 1999; Kemmis, 1995; Strand, Marullo, Cutforth, Stoecker, \& Donohue, 2003).

This research was conducted within the framework of a university-school district partnership with an understanding of the importance of and maximizing partnerships' impacts on educational reform (Author, 2010; Ball, 2005; Bryant \& West, 2004; Suarez-Balcazar, Davis, Ferrari, Nyden, Olsen, Alvarez, Molloy, Torro, 2004; Hunter, Munro, Dunn, \& Olsen, 2009; Maurrasse, 2001). Similar to the work of others, the Teacher Pipeline Project, a university-community-school partnership, provides stakeholders (i.e., research, educators, youth, parents,) from diverse background and social classes an opportunity to build authentic relationships focused on shared goals of educational and social change.

A unique dimension of The Teacher Pipeline Project includes partnerships between higher education and five school districts partners. The University of Utah, Salt Lake Community College, and five local school districts round out the partnership. As a collaborative, the Teacher Pipeline Project includes the more traditional elements of successful climates that impact student success (e.g., a supportive learning community, a common mission, and academic support structures (Smith, MacGregor, Matthews, \& Gabelnick, 2004). What program evaluation data findings indicated however were varied views from stakeholders regarding student participants and the perceived qualities they bring to the teaching profession.

\section{The Teacher Pipeline Project: A University of Utah-Salt Lake Community College Partnership}

Since its inception the Teacher Pipeline Project includes monthly board meetings, co-chaired by higher education and district representatives, where members manage the procedural and programmatic elements of the Teacher Pipeline Project. They also review applications, discuss available funding from each district (e.g., districts provide book costs and fees for scholarship recipients), and examine students' academic performance at both Salt Lake Community and the University of Utah.

Prior to matriculating to Salt Lake Community College, student scholarship recipients are identified as prospective teacher education students by participating school districts. Initial nominations by high school teachers, counselors, and or administrators are based upon interests in a teaching career, academic competencies, experience working with youth, membership in traditionally underrepresented communities, state residency, United States citizenship, and financial need.

For students who are selected to attend Salt Lake Community, tuition and funding for books and fees are provided for a two year course curriculum in teacher education. Faculty from the University of Utah and Salt Lake Community College oversee a required academic course sequence that is part of a curriculum agreement between the two higher education institutions. The course work across institutions serves as an institutional mechanism for increasing recruitment into a teacher education program that is both seamless and accessible to students who have historically begun their teacher education programs at community college.

Following graduation from the community college, Pipeline students complete their remaining bachelor's degree and licensure requirements at Utah. Course work includes but is not limited to: child development, assessment, research, content area teaching course work, student teaching, and a professional education seminar.

\section{Program Evaluation Findings}

Based upon early program evaluation data from student and project stakeholders, efforts to strengthen the transition support for student participants took many forms. For example support from high school, to the community college, and to the four-year institution included integrating more rigorous admissions requirements, providing stronger academic support and mentoring, and linking to families as supporters of educational success. Additionally, a bold effort was implemented in 2011 to shift the weekly seminar curriculum.

In addition to bolstering a college-level writing emphasis, assignments were strategically integrated through topics of social justice, white privilege, diversity, institutional racism, and the influence of families and communities on teaching and learning. Course readings, in-class discussions, and activities captured these themes and were presented with the intention of building leadership capacity among these future teachers (Arminio, Carter, Jones, Kruger, Lucas, Washington, Young, \& Scott, 2000; Komives \& Wagner, 2009).

\section{Project Curriculum}

Annual program evaluation data during years 2008-2010 identified: 1) inconsistencies in expectations for student participants and varied assumptions regarding participants' academic preparation; 2) the need for a curriculum specifically geared toward student participants; and 3) beliefs regarding the long-term success of students in the program. During its third year a curriculum revamp reflected shifts from an initial focus that was highly skill based and custodial. Additional support and mentoring were coupled with a focus on social justice literacy and leadership. In-class discussions and readings addressed historical practices that have limited opportunity in K-12 classrooms through examinations of classroom-based experiences that support or limit diverse learners. In essence, the curriculum was developed to do more than prepare future teachers to manage the technical logistics of teachers' work in 
urban communities.

A broadened definition of teachers' work exposed what Delgado Bernal, Aleman, and Garavito (2009) describe as spaces where traditionally underrepresented teachers see their roles in classrooms and schools in ways that challenge traditional views of dominant narratives. Because attitudes toward diversity impact student success in teacher education programs for underrepresented populations (McIntyre, Byrd, \& Foxx, 1996; Sleeter, 2001), the curriculum made central social justice while, simultaneously, allowing for reading and writing development.

These outcomes were evidenced most clearly in what stakeholders believed students should bring to the table as future teachers as well as crucial competencies among first-generation and students of color. Year III's program evaluation included in-depth views of participants' perspectives on the course curriculum through survey and interview data.

\section{Research Design and Data Analysis}

To evaluate the impact of a program curriculum on the Teacher Pipeline Project, data collection in year III of the program included both qualitative and quantitative methods designed to examine participants' perspectives. The quantitative data included a 5 point Likert-type questionnaire that examined participants' reactions to a seminar curriculum including but not limited to: history, culture, privilege, access, race, equity, socioeconomic status, gender, sexuality, immigration, service learning and activism, ableism, allies, and college reading and writing. Survey data were analyzed using descriptive statistics.

Qualitative data included open-ended survey questions and interview data. Questions included: "From your perspective, what should be key topics of study for students in the Teacher Pipeline Scholarship Program?" "In what ways, if any, should the unique contributions of students in the Teacher Pipeline project be considered when developing curriculum for the weekly seminar?" and "What should be the role of Utah and Salt Lake Community College in preparing future teachers?"

Open-ended data were examined through a process of constant comparison (Glaser \& Strauss, 1967). A matrix was constructed to facilitate data analysis (Miles \& Huberman, 1994). Initial categories were determined using a form of triangulation (Denzin, 1989). All names in this document are pseudonyms. In accordance with program evaluation and Institutional Review Board (IRB) policies both interview and survey data examined participants' perspectives on the Teacher Pipeline Project during years $1-3$.

\section{The Participants}

Eight of twelve community stakeholders and six student participants volunteered to complete a survey designed to identify perspectives on Pipeline student characteristics and the curriculum from a year-long seminar at Salt Lake Community College. Stakeholders included college partners and local school district representatives responsible for financial support and administrative oversight.

\section{Data Collection}

From a class of 15 student participants at Community (i.e., eight Latinas, two African-American women, one Asian American male student, with the remaining participants com- prised of White females) six students completed online surveys. Hour-long-follow-up interviews were conducted with four stakeholders and three student participants whom we identified as representative of the Teacher Pipeline Project stakeholders and students.

\section{Findings}

While survey response rate represents a subset of the total population findings are prompts for continued inquiry. Specifically, pilot survey and interview data reflected general agreement among stakeholders across survey questions, with notable variance in responses. Comparisons between stakeholders and student participants highlighted agreement on the value of college readiness and reading and writing competencies. All study participants viewed curriculum topics related to race and equity; inequalities in education; socio-economic status; and gender and sexuality as areas worthy of study. Distinctions emerged between project stakeholders and student participants on topics including: immigration, service learning, activism, and ableism. For project stakeholders, these topics, while important, were not considered primary areas of study. For student participants, these areas were deemed essential. Open-ended findings further revealed general to strong agreement on the value of collaboration, ownership, and the utility of monthly meetings for student participants.

For project stakeholders, the variance in perceptions of curricular topics was generally limited, though reading and writing skills were ranked highly. When asked to identify the importance of topics such as gender and sexuality and allies in education, stakeholders viewed the topics to be neutral to somewhat important.

Quantitative responses from student participants reflected general similarities in responses when compared with their stakeholder counterparts. Differences surfaced on questions related to allies in education, privilege and access, service learning and activism, and abelism in education. For each of these areas, student participants rated these areas as topics about which they strongly agreed as important dimensions of their course curriculum.

While survey data revealed general perspectives on specific curricular themes, open-ended survey responses highlighted more deeply embedded views regarding the characteristics for student participants, by both project stakeholders and student participants. Specifically, an analysis of open-ended feedback revealed a heightened focus among stakeholders' for academic skill development and administrative support for navigating enrollment scheduling, and accessing resources on campus (i.e., writing). When asked to identify the Pipeline's project goals, one stakeholder, Ellen, reported with enthusiasm,

This project is designed to identify, prepare, and select ethnic minority students interested in education/teaching while in high school. A community college, university along, and local districts will provide funding for orientations, financial aid coaching, advising, tutoring, and summer programs to support students as they transition to college with the goal to become engaged and successful in their college courses. The weekly seminar develops a community among students that will facilitate the identification of their vision for themselves as educators.

Ellen's appraisal of the logistics and long-term goals was technically accurate. And, as a Pipeline board member and 
project funder, her reactions echoed others' reflections on their efforts to shape the population of prospective teachers in the community. Her goals provided a reasonable scope and sequence for increasing participants' success.

Clearly financial support and personal guidance were identified as necessary dimensions of a support system. But situated within the laundry list of "must haves" are potential assumptions about students within the program that highlight, for some, shortcomings in what they bring, or fail to bring, to the teacher education program.

As a key stakeholder shared during an interview, Byron responded, “... we need to be careful about screening... make sure their 'academic deficit' is not so great that it outweighs the support available." Byron went on to highlight the importance of orienting students to scheduling, registration, books, college life, knowing peers, and understanding how to address their "weaknesses." While Byron's responses reflected a presumed deficit view of student participants' skill levels and the need for "significant remediation", he was also the only stakeholder to cite the importance of family and community support for student success. Byron's range of feedback illustrated the complexity of perceptions of traditionally underrepresented future teachers.

Byron expressed an awareness of the unique characteristics of life in urban classrooms and that student participants in the Teacher Pipeline Project would presumably possess the characteristics to be successful in those settings. What is less clear from Byron's and others' interviews are their intentions about what it takes to work in urban communities. That is, Byron and others often viewed those working in urban communities as in need of skill building and overall academic bolstering. What is less clear is what the underlying assumptions regarding these perceived weaknesses might presume.

When stakeholders were asked to identify the specific assets that student participants brought to the Teacher Pipeline Program, the majority of community stakeholders repeatedly highlighted academic support designed to enhance weak skills as a means of increasing academic "success". While some stakeholders recognized students' backgrounds, life experiences, and knowledge, this focus was secondary to basic skill development. Overwhelmingly, project stakeholders viewed the Teacher Pipeline Project as a valuable step toward cultivating a diverse teaching population as a tool for remediation what appeared as the "problems" affiliated with urban communities.

In contrast to stakeholders, student participants reinforced specifically their influence as future teachers, from underrepresented communities, as essential components of the seminar curriculum. That is, they believed it necessary to examine their unique contributions to the teaching profession as members of a nontraditional teaching community. Student feedback from Monica and Gina illustrated varied viewpoints on a program curriculum.

Monica, a first-generation Latina, plans to teach English. As her interview data indicated, her attention to issues of equity and access, as well as a social justice stance were not cited as critical to her success in the Teacher Pipeline Program, or as a future teacher. She noted in an end-of-the-year interview that issues of privilege and access are not areas of concern for her. She reported, "There are some minorities who have access... We have sometimes more opportunity... We are more privileged." She went on, "We don't see scholarships targeting White Protestant males." She added, "It is more about hard work... students applying themselves to succeed."

Gina, a Latina who has graduated from Utah, was asked to identify her views regarding the goals and curriculum in the Teacher Pipeline Project. Her responses were much different from those of Monica. Specifically, Gina reported,

I think one of the most important key topics that should be taught should be the privilege of being in the classroom [as part of the scholarship opportunity]... students should realize that not only is the committee counting on them but, future students in classrooms, and their families. Another topic that should be covered the first semester is the student's individualism. What can they bring to the scholarship class? What can the students bring to a university? What can the student participants bring into the future classroom?... In order to become a great teacher one must know how to work with different populations, organization skills, and good writing skills.

Gina also reported that no one curriculum area is more important than the others. She felt all areas were significant and allowed for a more comprehensive and global view of teaching for contemporary educators. She did distinguish between more generic views of diversity and the need for greater depth of understanding with regard to inequities in education. She felt this concept may be new to many future teachers.

As the differences between Monica's and Gina's feedback indicate, beliefs regarding the essence of teachers' work in areas related to access, equity, and social justice are individualized and unique to the range of people working in classroom and schools. Simply attracting first generation teachers and typically underrepresented teacher candidates does not ensure they will automatically respond to invitations to participate as educational allies or reform agents, simply because a scholarship and curricular focus are in place.

From a holistic review of the data from this evaluation, the most telling distinction between the reported perceptions of project stakeholders and student perspectives appeared in open-ended survey data regarding the goals of the curriculum. When stakeholders were asked to describe key topics of study for students in the Teacher Pipeline Project, they acknowledged broad conceptual issues related to: urban teaching, race, culture, and the influence of these prospective teachers on their communities. More frequently, though, stakeholders cited practical skills, academic rigor, and training on how to be successful college students as critical topics for the Teacher Pipeline Program seminar.

When the same question was asked of student participants, a different trend emerged. Conceptual issues related to working together as future teachers, building upon their backgrounds as assets to the teaching profession, and sharing information on recourses for underrepresented students were the primary areas of study. Logistics related to life in college, as well as detailed information on teaching programs were also cited by students. No student respondent addressed skill deficits, or the need for programs designed to remediate student participants' skills or academic competencies.

\section{Discussion}

Preliminary data collection on the curriculum affiliated with the Teacher Pipeline Program curriculum addressed important qualities for a nontraditional pool of prospective teachers, as well as the value of a proposed curriculum geared specifically to the needs of diverse, underrepresented communities. While a 
study limitation includes the small number of student responses, both student participants and partnership stakeholders noted the importance of strong academic preparation and the knowledge required to navigate higher education as essential for underrepresented teachers. Preliminary evaluation data further validated the importance of articulation agreements for course work across institutions of higher education; formal partnerships between two and four year institutions; alternate course opportunities; and active recruitment efforts. Deliberate marketing efforts, cohort formats, and ongoing support systems echo others' work for underrepresented student success in higher education (Burbank, 2010; Torres, Santos, Peck, \& Cortes, 2004).

While some stakeholders espoused a commitment to diversifying the teaching profession and recognized the assets of student participants, the goals of empowerment and voice were not always viewed as necessary. Further, variance among stakeholders on the qualifications of prospective teachers often implied subtle and not so subtle deficit undercurrents that reified a narrow prototype for students from underrepresented communities. Often times these beliefs were manifest through: perspectives on "appropriate" course work and programs of study; goals for preparing underrepresented teachers; and viewpoints on how underrepresented teachers will impact communities over time.

For student participants, survey and interview data signified greater optimism regarding the assets they would bring to the teaching profession. While the students understood the importance of strong academic skills, they welcomed a curriculum that examined a broad definition of diversity as preparation for their work in today's schools and communities.

Recruiting efforts for prospective teachers of color have varied in scope, intensity, and overall outcomes (Burbank, 2010, 2009; Donaldson, 2009; Torres, Santos, Peck, \& Cortes, 2004). Success for underrepresented individuals in college highlights the varied and complex nature of the factors that impact that success. Previous research identifies the very real need for support and preparation mechanisms that include: specific course work beginning in middle and high schools; financial aid; and dedicated attention to "gatekeeper courses" and their positive and potentially negative impact on students continuing in specific fields of study (e.g., math and science) (Crisp, Nora, \& Taggart, 2009).

The Teacher Pipeline Project findings extend previous research through conscious examinations of what constitutes adequate academic preparation and the knowledge of how to navigate higher education. The Teacher Pipeline Project data illustrated how university-community partnerships may influence prospective teachers of color in ways that reinforce historical perceptions of those who are best suited to teach through traditional views regarding qualifications and programs of study.

While the goal of a relevant curriculum may appear straightforward, pronouncements of a common understanding among stakeholders must be defined and consistently evaluated. The varied perspectives among stakeholders in this project highlighted how beliefs may unintentionally inhibit prospective teachers of color through excessive attention to skill development and/or remedial support. Since the Teacher Pipeline Program's inception, three students have graduated from Utah, with eight students currently enrolled.

Finally, project findings raised challenging questions regarding the differences in stakeholders' and student participants' views of a curriculum for underrepresented teachers. The realities of college are daunting, particularly among first-generation college students. However these challenges must be addressed systematically without defaulting to profiles of prospective teachers whose academic potential is framed as needing remediation and superficial skill development. Recruiting efforts must strategically foster and welcome varied backgrounds, assets, and ways in which life experiences positively impact all communities within teacher education programs.

\section{Conclusion}

The success or failure of the Teacher Pipeline Project is not obvious at this juncture. The number of Teacher Pipeline Project students nearing the end of a four-year licensure program is small (i.e., one Utah graduate in 2011; two in 2012; two in 2013 and six students entering Utah in fall of 2012.) In addition to high attrition rates among those in the community college during the first two years, those needing additional time to complete their programs was significant. As a result it is not clear how curricular themes introduced at the community college will impact dispositions and overall performance once students near the end of their degree and licensure programs.

The lessons learned from this investigation include the implementation of additional efforts designed to increase program completion at Utah by Pipeline students through a multilayered approach to diversifying the teaching profession. In addition to academic support the following components are institutionalized components at Utah: 1) transitional support through Utah's Peer Advocacy Program (i.e., a peer-based mentoring program in the teacher education programs - description located at http://uite.utah.edu/asuu-mentors/index.php); 2) support by a transition counselor who also serves as an outreach and recruitment coordinator with Salt Lake Community; and 3) formalized linkages to academic support at Utah include but are not limited to connections with the university's writing center and academic student support office.

An additional support mechanism at Utah is a version of the 2007 University California Los Angeles (UCLA), Chicano Studies Research Report program. In partnership, the University of Utah and Salt Lake Community College support summer transition workshops for students as they transfer from Salt Lake Community to Utah (Rivas, Perez, Alvarez, \& Solarzano, 2007). Mirrored after the UCLA program, a two-day workshop provided students with guidance on accessing recourses at Utah; uncovering "insider" knowledge that promotes success at Utah (e.g., knowledge of faculty allies, opportunities to engage with other underrepresented students); and offering explicit guidance on program requirements and program completion that must be considered systematically (e.g., ceasing outside employment during student teaching).

Through additional systemic efforts, linkages to families began in 2010 and provided dedicated family support through orientations to the Teacher Pipeline Project and its affiliated requirements. Families and caregivers of student project participants completed formal meetings and information sharing opportunities to more clearly define, from their perspectives, how family support contributes to student success in K-16 settings. These same family members will serve as future ambassadors to families whose children are interested in the teaching profession. Understanding the assets of families and communities, including language, is essential to building systemic sup- 
port for future teachers and those affiliated with school systems (Burbank, 2011; Kugler \& Acosta Price, 2009; Stratton, Ooka Pang, Madueňo, Park, Atlas, Page, \& Oliger, 2009).

The outcomes from the Teacher Pipeline Project extend past discussions on community-based efforts to diversify the teaching profession (Burbank, 2009, 2010; Genzuk \& Baca, 1998; Recruiting New Teachers, 2003; Torres, Santos, Peck, \& Cortes, 2004). Past projects highlight the significance of vigilant attention to definitions of success that have historically embedded deficit perspectives through perseveration on basic skills measured through traditionally defined performance competencies (e.g., standardized test scores).

Responsive teacher recruitment efforts must recognize how factors such as variance in curriculum and pedagogy capitalize on the assets brought to the teaching profession by individuals from traditionally underrepresented communities. As one stakeholder expressed, "... as teachers of teachers we must draw upon our students' perspectives on how schools helped or hindered their education in ways that foster their voices as advocates for others." Without critical examinations of the nuances of recruitment efforts, teacher education programs will remain static. Alternatively, responsiveness to dynamic communities must recognize individual histories, communities, and families as factors impacting success for all members of K-16 communities.

\section{REFERENCES}

Andrews, D. (2009). The hardest thing to turn from: The effects of service learning on preparing urban educators. Equity \& Excellence in Education, 42, 272-293. doi:10.1080/10665680903060261

Arminio, J. L., Carter, S., Jones, S. E., Kruger, K., Lucas, N., Washington, J., Young, N., \& Scott, A. (2000). Leadership experiences of students of color. NASPA Journal, 37, 496-510.

Ball, W. J. (2005). From community engagement to political engagement. Political Science and Politics, 38, 287-291. doi:10.1017/S1049096505056507

Bryant J., \& West, M. (2004). Mutual benefits that can accrue to universities and communities from the interactions with each other. New Directions in Civic Engagement: University Avenue Meets Main Street, Pew Partnership for Civic Change, 1, 80-89.

Burbank, M. D. (2011). Reform begins at home: A 21st century response to teacher education. In M. Issa Saleh, \& K. S. Myint (Eds.), Teaching teachers: Approaches in improving quality of education (pp. 99-116). New York: Nova Publishers.

Burbank, M. D., \& Hunter, R. (2010). Families, Intercollegiate Collaboration, and Routes to Studying Teaching. In R. David, \& J. Slater, (Eds.), Collaboration in education (pp. 183-190). New York: Routledge.

Burbank, M. D., Bates, A., \& Schrum, L. (2009). Expanding teacher preparation pathways for paraprofessionals: A recruiting seminar series. Teacher Education Quarterly, Spring, 36, 201-216.

Buys, N., \& Bursnall, S. (2007). Establishing university-community partnerships: Processes and benefits. Journal of Higher Education Policy and Management, 29, 73-86. doi:10.1080/13600800601175797

Campbell, J. R. (1999). Reclaiming lost heritage: Land grant and other education initiatives for the twenty-first century. Boston, MA: Iowa State University Press.

Cochran-Smith, M. (2004). Walking the road: Race, diversity, and social justice in teacher education. New York: Teachers College Press.

Crisp, G., Nora, A., \& Taggart, A. (2009). Student characteristics, pre-college, college, and environmental factors as predictors of majoring in and earning STEM degree: An analysis of students attending a Hispanic serving institution. American Educational Research
Journal, 46, 924-942. doi:10.3102/0002831209349460

Delgado Bernal, D., Aleman, E., \& Garavito, A. (2009). Latina/o undergraduate students mentoring Latina/o elementary students: A borderlands analysis of shifting identities and first-year experiences. Harvard Educational Review, 79, 560-585.

Denzin, N. K. (1989). The research act (3rd ed.). Englewood Cliffs, NJ: Prentice Hall.

Donaldson, M. (2009). Into-and out of-city schools: The retention of teachers prepared for urban settings. Equity \& Excellence in Education, 43, 347-370. doi:10.1080/10665680903034753

Excelencia in education (2009). URL (last checked 16 February 2009). www.edexcelencia.org

Flores, B. B., Clark, E. R., Claeys, L., \& Villarreal, A. (2007). Academy for teacher excellence: Recruiting, preparing, and retaining latino teachers through learning communities. Teacher Education Quarterly, 34, 53-69.

Frankenberg, E. (2009). The demographic context of urban schools and districts. Equity \& Excellence in Education, 42, 255-271. doi: $10.1080 / 10665680903032294$

Gay, G. (2010). Acting on beliefs in teacher education for cultural diversity in teacher. Journal of Teacher Education, 6, 143-152. doi:10.1177/0022487109347320

Gay, G. (2002). Preparing for culturally responsive teaching. Journal of Teacher Education, 53, 106-116. doi: $10.1177 / 0022487102053002003$

Gay, G., Dingus, J., \& Jackson, C. (2003). The presence and performance of teachers of color in the profession (a monograph). Washington, DC: Community Teachers Institute.

Genzuk, M., \& Baca, R. (1998). The paraeducator-to-teacher pipeline: A five year retrospective on an innovative teacher preparation program for Latina(os). Education and Urban Society, 31, 73-88. doi:10.1177/0013124598031001006

Glaser, B., \& Strauss, A. (1967). The discovery of grounded theory. Chicago: Aldine.

Guarino, C. M., Sanatibañez, L., \& Daley, G. A. (2006). Teacher recruitment and retention: A review of the recent empirical literature. Review of Educational Research, 72, 173-208. doi: $10.3102 / 00346543076002173$

Hunter, R., Munro, S., Dunn, L., \& Olsen, K. (2009). Bridging university and community: The power of collaborative partnerships for social change. In K. Mohrman, J. Shi, S. E. Feinblatt, \& K. W. Chow (Eds.), Public universities and regional development (pp. 289-311). Chengdu: Sichuan University Press.

Hodgkinson, H. (2002). Demographics and teacher education. Journal of Teacher Education, 53, 102-105. doi: $10.1177 / 0022487102053002002$

Kane, P., \& Orsini, A. (2005). The colors of excellence: Hiring and keeping teachers of color in independent schools. New York: Teachers College Press.

Kemmis, D. (1995). The good city and the good life: Renewing a sense of community. New York: Houghton Mifflin Company.

Komives, S. R., \& Wagner, W. (2009). Leadership for a better world: Understanding the social change model of leadership development. San Francisco, CA: Jossey-Bass.

Kugler, G., \& Acosta Price, O. (2009). Go beyond the classroom to help immigrant and refugee students succeed. Phi Delta Kappan, 41, 48-52.

Maurrassee, D. (2001). Beyond the campus: How colleges and universities form partnerships with their communities. New York: Routledge.

Miles, M. B., \& Huberman, A. M. (1994). Qualitative data analysis: An expanded sourcebook (2nd ed.). Thousand Oaks, CA: Sage.

McIntyre, D. J., Byrd, D. M., \& Foxx, S. M. (1996). Field and laboratory experiences. In J. Sikula, T. J. Buttery, \& E. Guyton (Eds.), Handbook of research on teacher education (2nd ed., pp. 171-193). New York: Macmillan.

National Center for Education Statistics (2003). The condition of education. Washington, DC: Department of Education.

Nieto, S., \& Bode, P. (2008). Affirming diversity: The sociopolitical context of multicultural education (5th ed.). New York: Pearson.

Perlich, P. (2011). Census 2010: A first look at State Name results. 
State Economic business review, 71, 2-15.

Perlich, P. (2002). State name minorities: The story told by 150 years of census data. Salt Lake City, UT: The University of Utah.

Recruiting New Teachers, Inc. (2003). Paraeducators programs. URL (last checked 4 April 2012).

http://www.ericdigests.org/2002-3/paraeducators.htm

Rivas, M., Perez, J., Alvarez, C., \& Solarzano, D. (2007). UCLA Chicano Studies Research Report (2007). Latina/o transfer students: Understanding the critical role of the transfer process in California's postsecondary institutions. Los Angeles, CA: UCLA Latino Research Program.

Sleeter, C. (2001). Preparing teachers for culturally diverse schools: Research and the overwhelming presence of Whiteness. Journal of Teacher Education, 52, 94-106.

Stanford, B. (1999). Tapping the wisdom of positive, persevering teachers: The South Central L. A. study. The Annual Meeting of the American Educational Research Association. Montreal.

Strand, K., Marullo, S., Cutforth, N., Stoecker, R., \& Donohue, P. (2003). Community-based research and higher education. San Francisco, CA: Jossey-Bass.
Stratton, T., Ooka Pang, V., Madueňo, M., Park, C., Atlas, M., Page, C., \& Oliger, J. (2009). Immigrant students and the obstacles to achievement. Phi Delta Kappan, 41, 44-47.

Suarez-Balcazar, Y., Davis, I., Ferrari, J., Nyden, P., Olsen, B., Alvarez, J., Molloy, P., \& Toro, P. (2004). University-Community Partnerships: A framework and an exemplar. In L. Jason, C. Keys, Y. SuarezBalcazar, R. Taylor, \& M. Davis. (Eds.), Participatory Community Rsearch: Theories and methods in action (pp.105-120). Washington DC: American Psychological Association.

Swartz, E. (2003). Teaching white preservice teachers: Pedagogy for change. Urban Education, 38, 255-278.

Torres, J., Santos, J., Peck, N., \& Cortes, L. (2004). Minority teacher recruitment, development, and retention. Providence, RI: The Education Alliance at Brown University.

United States Census Bureau (2008). URL (last checked 23 October 2012).

http://www.census.gov/acs/www/data_documentation/2008_release/

Villegas, A., \& Lucas, T. (2002). Educating culturally responsive teachers: A coherent approach. Albany, NY: SUNY Press. 